\title{
From Paris To London: The Legal History of European Reparation Claims: 1946-1953
}

\author{
Richard M. Buxbaum*
}

\author{
INTRODUCTION: THE EARLY HISTORY AND WHY IT MATTERS
}

The umbrella concept of reparations, including its compensatory as well as restitutionary aspects, regretfully remains as salient today as it was in the twentieth century. A fresh look at its history in that century, and how that history shapes today's discourses, is warranted. This study is warranted in particular because the major focus in recent decades has been on the claims of individual victims of various atrocities and injustices - generalized as the development of international human rights law by treaty, statute, and judicial decision. One consequence of this development is that the historical primacy of the state both as the agent for its subjects and as the principally if not solely responsible actor is ever more contested.

How did this shift from state responsibility and state agency over the past half-century or more occur? Considering the apparent primacy of the state in this context as World War II came to an end, do the shortcomings of the inter-state processes of the early postwar period provide a partial explanation of these later

\footnotetext{
* Jackson H. Ralston Professor of International Law (Emeritus), University of California, Berkeley, School of Law. My thanks to a number of research assistants, in particular Lisa Pfitzner, Sonya Hymer, Niilana Mutama, and Rachel Anderson; my thanks also to David Caron and the late Gerald Feldman for critical reading of the manuscript and good advice. Even more than in the usual case it should be emphasized that errors of fact and interpretation are my own.

Some disclaimers and disclosures: These are my personal views; they do not derive from and should not be attributed to the Property Commission of the German Foundation for Remembrance, Responsibility, and the Future, of which I was the U.S. member, to its staff, or to the appointing authority (U.S. Department of State). For personal reasons I have been interested in the issues discussed herein, and had some peripheral engagement with them, for many years. I was a consultant to counsel representing some of the defendants in the U.S. litigation that was settled by the U.S.-Germany agreement leading to the creation of the mentioned Foundation: United StatesGermany Agreement concerning the Foundation "Remembrance, Responsibility and the Future," July 17, 2000, reprinted in 39 I.L.M. 1298 and Gesetz zur Errichtung einer Stiftung (Erinnerung, Verantwortung und Zukunft), Aug. 2, 2000, I BGBl. 1263. I also prepared a pro-bono brief as amicus curiae in the litigation mentioned in note 86 below.
} 
developments? The main thesis of this Article is that failures in the inter-state reparations processes led to the rise of the individual's agency in the international sphere. This Article's second thesis is that the failure of these firststage collective efforts played a significant role in the shift towards bilateral treaties that could compensate in part for that failure. Woven into that thesis, at least indirectly, is another line of inquiry; namely, into the fate of efforts of those Allied Powers that had been occupied by Germany during the war to obtain reparations. This may well be a separate strand with fewer connections to the questions concerning the rise of the individual subject's own agency; but as the early postwar history is common to both of these later developments, it also is an element of this narrative.

The discussion begins with the first coordinated effort of France, the United Kingdom, and the United States to search for a multilateral process for the division of the reparations that the four major powers had agreed to, as soon as the Soviet Union's unilateral approach to reparations was accepted as a fait accompli. That division was memorialized in the Potsdam Agreement of August 1945, in which the Soviet Union, the United Kingdom, and the United States, with the later reluctant acquiescence of France, in essence left reparations to their respective spheres of influence. ${ }^{1}$ The agreement did allocate to the Soviet Union twenty-five percent of whatever productive (industrial) assets the Western Powers might choose to claim as reparations, but left the remaining seventy-five percent for allocation among all Western Allies.

Part I discusses the allocation episode following the Potsdam Agreement. Part II focuses on the slow erosion of early hopes among those Allies who had been under German occupation for a meaningful transfer of monetary and physical assets under the reparations arrangements that evolved. ${ }^{2}$ Part III turns to a major, and in a sense separate component of the early reparations efforts; namely, the search for monetary gold seized by the German occupation regimes and to a large extent used by Germany to pay for transactions with the wartime Neutrals, in particular Switzerland. Part IV addresses the recapture and reallocation of monetary gold among the Allies. Part V briefly introduces the

1. The best sources of the Potsdam Protocol of August 2, 1945 are the Protocol of the Proceedings of the Berlin Conference, in 2 ForEIGN RELATIONS OF THE UNITED STATES: Diplomatic PAPERs: The Conference OF Berlin (The PotSDAM ConferenCE), 1945, at 1478-98 (1945), and the same as reprinted in SEnAte Comm. on Foreign Relations, A DeCAde of AMERICAN FOREIGN POLICY: BASIC DOCUMENTS, 1941-49, (1950), available at $\mathrm{http}: / /$ avalon.law.yale.edu/20th century/decade17.asp. See its review from this reparations context in Richard Buxbaum, A Legal History of International Reparations, 23 BERKELEY J. INT'L L. 314 (2005) [hereinafter Legal History].

2. As will become clear below, the Soviet Union, while partly and temporarily occupied, had its own means to satisfy this demand. France, while later also an Occupation Power, had considerably less power in this regard. The exclusion of the formerly occupied countries later in the Soviet sphere of influence from this later bilateral treaty regime also needs to be noted. In short, the statement in the text, and its suggestion of a connection between early collective failure and later bilateral treaty recoupment processes principally applies to the smaller Western European Allies. 
subject of the gold and other valuables taken from or left by individual victims of the Third Reich regime. The final part concludes.

I.

\section{THE EARLY REPARATIONS NEGOTIATIONS}

The Paris Agreement on Reparations of January 14, 1946 ("Paris Agreement" or "the Agreement") ${ }^{3}$ among the Western Allies (which at that time still included Albania, Czechoslovakia, and Yugoslavia) essentially provided for the division of anticipated German reparations, but left their absolute size and nature to later determination. In essence, only France, the United Kingdom, and the United States had the authority to make those determinations. In addition, the timing and rate of distribution of German reparations to the other, formerly occupied Allies also rested with these three powers. ${ }^{4}$ As these decisions crawled through time, the emerging Cold War and the resultant international and domestic political considerations important to France, the United Kingdom, and the United States led to a substantial reduction of hopes and expectations to obtain a decent level of these resources. Nevertheless, the reality of adequate reparations was still largely in the unknown future as the process of implementation of the Agreement began.

The Paris Conference understandably focused on the nature of the resources that the aforementioned Allied states might claim from Germany and its wartime partners. That non-state persons and institutions might also lay claim to these resources was relevant only in a subsidiary or derivative sense. Organizations representing Jewish survivors and the larger community of Displaced Persons were the objects of consideration in this resource-allocation process, but only in a limited way were they subjects or agents participating in, let alone shaping these decisions. ${ }^{5}$

The Paris Agreement established three separate reparation tracks, characterized by the nature of the resources that were under discussion as suitable for reparation purposes. Each of those tracks is important from the perspective of this Article because the first hints of conflict between state and individual claimants arose by reason of the nature of these resources. Physical assets found in the Western Zones of Germany would be subject to return to any

3. The Agreement on Reparation from Germany, on the Establishment of Inter-Allied Reparation Agency and Restitution of Monetary Gold, Jan. 14, 1946, 61 Stat. (3) 3191 [hereinafter Paris Agreement]. It was implemented as to the support of the victims of the Nazi regime by the Agreement on a plan for allocation of a reparation share to nonrepatriable victims of German action of June 14, 1946.

4. See Buxbaum, Legal History, supra note 1, at 332ff. An earlier full discussion of these and later episodes, though from the perspective of the contested claims of exclusivity of the interstate settlement process, is found in Rudolf Dolzer, The Settlement of War-Related Claims: Does International Law Recognize a Victim's Private Right of Action-Lessons After 1945, 20 BERKELEY J. INT’L L. 296 (2002).

5. This is discussed more fully in Buxbaum, Legal History, supra note 1, at $335 \mathrm{f}$. 
signatory country, which could provide evidence that it or its subjects had had a significant financial interest in either the particular asset or a group of fungible similar assets. These returned assets - or their monetary value if liquidatedwould be charged against that country's percentage allocation of tangible assets granted under the Agreement. ${ }^{6}$ This, in short, was the restitutionary component of the reparations arrangement.

The second track was comprised of two types of assets not originally taken by German occupation forces and thus not subject to the restitution concept. One defined category ("B") was industrial (i.e., productive capital) equipment to be taken from Germany, as well as German merchant ships and inland water transport. This category was under the decision-making authority of the InterAllied Reparation Agency (IARA) created by Part III of the Agreement, an agency that itself was in turn subject to the actual asset-removal determinations of the Allied Control Council. The remaining, undefined category ("A") consisted of all other physical and financial assets. In addition to assets located in the German territory, this also included what were generally known as German external assets-those located in neutral countries as well as in the signatory Allied countries. ${ }^{7}$ The first $\$ 25,000,000$ of the German external assets found in neutral countries were to be paid to a fund for the support of the Displaced Persons community, many of them in essence stateless victims of Nazism - a decision largely attributable to representatives of that community and supported principally by the United States. ${ }^{8}$

Category A also included such dwindling and eventually illusory assets as deliveries of industrial production to be made to the West from the Soviet Zone. In addition, it tangentially included the prickly issue of German prisoner of war labor. The United Kingdom at one point argued that the value of forced labor by German prisoners of war held after the termination of hostilities also should be included as a debit against the benefiting country's allocation of assets received on this track. ${ }^{9}$ This argument focused primarily on France, which claimed the

6. Paris Agreement, supra note 3, Part I, art. 4(C)(i) (“Any item or related group of items in which a claimant country has a substantial prewar financial interest shall be allocated to that country if it so desires ...").

7. Id. Part I, art. 6. The disposition of these external assets, however, differed depending on whether located in neutral or Allied countries. Privately owned German assets in Allied countries had been frozen at the beginning of the war, and were now vested (i.e., confiscated) there. They were made subject to a species of self-help reparations, to be treated as credits under the Paris Agreement's distribution arrangements. Assets in neutral countries were to be subject to later arrangements with those countries, as discussed below, including a first charge in favor of relief and rehabilitation of displaced persons.

8. Buxbaum, Legal History, supra note 1, at 336-37; The Ambassador in France (Caffery) to the Secretary of State, 3 Foreign Relations of the United States: Diplomatic PaPers 1451 (1945).

9. Buxbaum, Legal History, supra note 1, at 344; The Ambassador in France (Caffery) to the Secretary of State, 3 Foreign Relations of the United STATES: Diplomatic PAPERS 1382-83 (1945). 
right to require this service and exercised it until $1947 .{ }^{10}$ Not surprisingly, a bitter and sensitive political battle erupted over this proposal. The United States finally sided with France in rejecting this category, though under the condition that the repatriation of these prisoners of war be hastened and that they not be required to engage in dangerous service such as mine clearing. ${ }^{11}$ The third track dealt with monetary gold Germany looted or wrongfully removed from the occupied countries during the war. Part II, below, discusses this track in more detail.

Finally, some reparations, but only to specific victim-states, were to be paid by the other Axis members and the co-belligerent Finland. This was done pursuant to the Peace Treaties - treaties the Paris Agreement itself anticipatednegotiated among all Allies and then put before these Axis states at the Paris Conference of Ministers of July-August 1946. Bulgaria, Finland, Hungary, Italy, and Romania had little choice and little negotiation room, and signed them in February of $1947 .^{12}$ Austria-which came into the enjoyment of victim status for reasons not immediately obvious then or now-is another story. Austria signed its Treaty of Peace in 1955, when its quasi-occupation status by East and West ended; the treaty did not require Austria to make general reparation payments (as distinguished from restitution of identifiable property found there after the war). ${ }^{13}$

10. See 13 Kurt W. Böhme, Zur Geschichte der Deutschen KriegsGefangenen des Zweiten Weltkriegs: Die Deutschen KRIEgsgefangenen in FranZÖsischer Hand 127ff (Erich Maschke ed., 1971) for an account of the retention of German prisoners of war in France and the relatively late date of their release, in particular the review of repatriation categories and dates. This work relies in turn for much of its data on a French analysis prepared in 1948 by the Direction Générale des Prisonniers de Guerre de l'Axe (Rapport Buisson), which apparently was only available in mimeographed format and was not preserved. Much of its substance may be found in Jean Hurault, Les Camps de Prisonniers de Guerre Allemands en Bretagne (1944 À 1946) (2004), available at http://bastas.pagesperso-orange.fr/pga/camps-francais/list-camps-bret.htm, a reference Professor Vivian Grosswald Curran kindly provided me.

11. See Memorandum of Understanding on Repatriation and Liberation of Prisoners of War, Mar. 13, 1947, T.I.A.S. 2405 (memorializing an understanding reached concerning especially the terms of release of those German prisoners of war captured by American forces and turned over to the French).

12. Treaty of Peace with Bulgaria, Feb. 10, 1947, 61 Stat. (2) 1915, 41 U.N.T.S. 21; Treaty of Peace with Hungary, Feb. 10, 1947, 61 Stat. (2) 2065, 41 U.N.T.S. 135; Treaty of Peace with Italy, Feb. 10, 1947, 61 Stat. (2) 1945, 49 U.N.T.S. 3; Treaty of Peace with Romania, Feb. 10, 1947, 61 Stat. (2) 1757, 42 U.N.T.S. 3. The Treaty of Peace with Finland, Feb. 10. 1947, 48 U.N.T.S. 203, was not signed by the United States, since the two countries had not been at war with each other despite Finland's role as a co-belligerent of Germany. The background to that state of affairs is an interesting but separate story. For a useful review thereof see generally R. MiCHAEL BERRY, AMERICAN FoREIGN POLICY AND THE FINNISH EXCEPTION (1987). For a detailed analysis of these treaties' provisions, demonstrating the limited latitude remaining to these Axis Powers in defining the scope of their obligations, see CORNELIUS PAWLITA, "WIEDERGUTMACHUNG" ALS RECHTSFRAGE? 146-54 (1993).

13. Austrian State Treaty, May 15, 1955, 217 U.N.T.S. 223 (1055). For a review of Austrian compensation of its own persecuted subjects, including the recent legislation enacted in consequence of U.S.-Austrian negotiations, see generally Eric Rosand, Confronting the Nazi Past at the End of 
From January 1946 to mid-1949, three collection efforts based on the Paris arrangement (and the separate arrangements with the Neutrals, especially Switzerland) take center stage. There is the implementation of the smaller Allies' share of reparations expected by those of them that had been occupied but had no occupation zone of their own. ${ }^{14}$ There is the search for German monetary gold ${ }^{15}$ looted by German occupation forces, to be shared by all Allies under the monetary-pool arrangement. ${ }^{16}$ There is the effort to procure German private-sector assets located in neutral countries ${ }^{17}$ and, for different disposition, ${ }^{18}$ in the Allied countries. As a separate element, though indirectly relevant to both efforts, there is the implementation of the promise to fund the support of the redefined Displaced Persons communities by means of assets that, as categories, coincided with those being sought by these Allies. ${ }^{19}$

These various collection efforts are the subject of this Article. The review of their fruits is an important prelude to the temporally concurrent other two stages of the postwar story: the expansion of reparations, restitution, and compensation claims to encompass private claimants; and the resolution of prewar debt claims and postwar state occupation-cost claims as these collection efforts impacted on private claimants and on their conflicted relations with interstate claims and claimants. The review of those stages, however, is beyond the scope of the present Article and requires separate treatment.

the 20th Century: The Austrian Model, 20 Berkeley J. INT'L L. 202 (2002). For the ongoing decisions of the Commission, see JOSEF AICHER ET AL., ENTSCHEIDUNGEN DER SCHIEDSINSTANZ FÜR NATURALRESTITUTION, Vol. 1-5, (2008-2012) (bilingual German/ English).

14. "Allies" unless otherwise specified identifies only the "Western Allies" of the Paris Reparations Agreement, whether the assets at issue are physical or financial, German or external. This is addressed further, infra Part III.

15. "Monetary gold" refers to stocks of gold in occupied Allied countries looted by German occupation forces. This is addressed further, infra Part IV.

16. The related search for non-monetary gold and similar valuables (including both confiscated items and those harvested from the corpses of the murdered victims) is discussed infra Part V. The disposition of German private-sector assets is a separate issue though it overlaps to some degree with the searches called for by the Paris Agreement. See infra Part III. These assets were located in Allied countries and frozen there by wartime legislation, or frozen in neutral countries under similar wartime legislation, and then sought for turnover after the war through separate agreements of these Neutrals with the Allies.

17. Of course, the search for looted monetary gold also implicated the Neutrals, principally Switzerland. See infra Part III.

18. Basically, though not exclusively, in partial reimbursement of those countries' war-waging costs.

19. Buxbaum, Legal History, supra note 1, at $336 \mathrm{f}$. 
II.

\section{FAILING HOPES AND EXPECTATIONS OF THE FORMERLY OCCUPIED ALLIED COUNTRIES}

The first narrative can be sketched briefly. It reveals the diminishing hopes for any significant implementation of the smaller Western Allies' shares of reparations. It is reflected in the increasingly despondent annual reports of the IARA, the institutional arm of the Paris Agreement's signatories. ${ }^{20}$ The IARA, as already mentioned, ${ }^{21}$ was dependent upon the decisions of the three Western Occupation Powers - nominally made within the framework of the Four-Power Allied Control Council—for deliveries of both industrial equipment and industrial output from their zones. Those decisions were based on factors among which the reparations allocation was only one, and one less and less dominant. A number of factors were largely responsible for the creeping failure of this mechanism to achieve meaningful reparations: the emerging Cold War; the increasingly successful campaign of German industry and labor union leaders against the program; a U.S. Congress that was unsympathetic if not hostile towards the subtle distinctions between supporting German reconstruction with Marshall Plan funds and dismantling excess German (military-) industrial capacity; and the simple evaporation of resolve. ${ }^{22}$

The Treaties of Peace that the four Occupation Powers forced Bulgaria, Finland, ${ }^{23}$ Hungary, Italy, and Romania to sign and ratify in 1947 also called for, and in the end actually resulted in, some cash and in-kind payments by these states to their respective victim-beneficiary states, as was prescribed in the Paris Agreement. Those reparations, however, were also far below the level that Allied states had reason to expect, or at least to hope for, when they left the table in Paris with the January 1946 Agreement. They were to be credited against allocations that the Agreement had set forth but were not a complete substitute

20. Id. at $332,334$.

21. See supra Part I.

22. This was especially true after 1948. Important elements within the U.S. Republican Party had pressed the argument for the sanctity of private property, even of subjects of the Axis, from 1945. However, with the advent of the Cold War and the imminent return of German sovereignty, the Truman Administration also moved in this direction. The critical turning point was the Foreign Assistance Act of 1948, Pub. L. No. 80-472, 62 Stat. 137, pursuant to which the Industrial Advisory Committee under George Humphrey reviewed the Western Zonal Commanders' list of German enterprises slated for reparations transfer, in order to determine which ones would best be left in place to aid European economic recovery. See The Humphrey Committee Proposals of the United States Government, in 3 Foreign Relations of the United STATES: COUNCIL OF Foreign MINISTERS: GERMANY AND AUSTRIA 569-72 (1949).

These policies, despite the Cold War blanket, were nonetheless controversial, especially given the pre-war involvement of some of the American industrialists with their Third Reich counterparts. For a taste of this lingering bitterness, specifically in the context of the Humphrey Report, see George G. Sadowski [D. Mich.], Extension of Remarks: Our Reparations Experts (Feb. 2 , 1949) (transcript available in Box 6 of the University of Oklahoma's Wilson Collection).

23. In the case of Finland, only three since the United States had not been at war with Finland. 
for those allocations. Indeed, their principal beneficiary was the Soviet Union, which was understandable in the case of the Peace Treaties with the Eastern Axis states and Finland. ${ }^{24}$ The other beneficiaries were Czechoslovakia, Greece, and Yugoslavia; but the amounts, as stated, were minor.

In short, by 1951, when these states were summoned back to the negotiation table for the reorganization and rescheduling of the various components of prewar and postwar German debts, the best they could do, as described more fully below, was to avoid the formal extinguishment of their theoretically still outstanding claims.

The small size of these transfers is the principal reason why the original expectation that adherence to the Paris Agreement implied a waiver of further claims by its signatories against Germany ${ }^{25}$ could not be maintained. Whether taken alone or in conjunction with the occasional transfer of some German physical assets from within Germany, they could not be counted on to satisfy the implicit understanding on the basis of which the obligation of exclusivity had been imposed on these Allies by the three Western Occupation Powers at Paris. In private-law terms, the synallagmatic structure of the contract simply was not achieved in the implementation of that Agreement. In addition, it was by no means clear that the Paris Agreement by its terms did express a waiver. Article 2B of the Agreement specified that it was "without prejudice to ... the right which each signatory government may have with respect to the final settlement of German reparations." 26 More specifically, even as to the waiver language of Article 2A, it was noted as early as 1953 that "in certain authoritative quarters it is believed that in this section of the agreement the signatory powers merely settled claims among themselves with respect to German assets . . .."27

The same dispute concerning the waiver of further claims in essence also arose as to the mentioned 1947 Peace Treaties with the other Axis countries and Finland, though in this case less in regard to state claims than to the individual claims of persecuted subjects of those states. The 1947 Peace Treaties included a complex series of waivers of claims of these Axis members or cobelligerents against Germany. ${ }^{28}$ In essence, these waiver provisions purported to waive-for the state and its nationals - all claims against Germany and its nationals outstanding at war's end other than prewar contract claims. ${ }^{29}$ The "state waiver"

24. The amounts are tabulated in the Report of the War Claims Commission, H.R. REP. NO. 67, at 33 (1953) [hereinafter War Claims Report]. Bulgaria, the only Axis member already by then in the Soviet orbit, was spared any obligation to the Soviet Union, and charged only with minor reparations payable to Greece and Yugoslavia. Treaty of Peace with Bulgaria, Feb. 10, 1947, art. 21, ๆ 1 , 61 Stat. 1915, 41 U.N.T.S. 21.

25. And — a separate argument—of the claims of those signatories' subjects against Germany.

26. Paris Agreement, supra note 3, art. 2B. See also supra Part I.

27. War Claims Report, supra note 24, at 49 n.49.

28. See supra note 12.

29. See generally EBERHARD MENZEL, DIE FordERUNGSVERZICHTSKLAUSELN GEGENÜBER DEUTSCHLAND IN DEN FRIEDENSVERTRÄGEN VON 1947 (1955) (in which the effect of these 
is understandable given the fact that these countries were members of or cobelligerents with the Axis. They maintained their own governmental structures, admittedly under greater or lesser degrees of German overlordship; their wartime economic relationships with Germany were at least nominally those of equals; and their subjects' economic losses were not going to receive the ascription of coercion from which the subjects of the occupied countries benefited after the war.

The Hungarian, Italian, and Romanian waivers, however, also had an additional cast that bears on the issue of persecution, though a cast that differs in each specific national case. Had they been taken literally, these waivers would have collided with the fact that in Hungary and Romania, and to a considerable degree even in Italy, substantial populations of persecuted subjects existed. These countries' peace treaties precluded state support of compensation from Germany of the type that the racial, religious, and political victims of German and Allied nationality would begin to receive as the early postwar chaos settled into something resembling stability.

Some of this reality is already reflected in these peace treaties. Thus, as far as property restitution was concerned, the Hungarian and Romanian treaties specifically required restitution (or compensation) to their own victims of persecution, albeit only by these states, not by Germany. ${ }^{30}$ While a fuller discussion of this whole issue is beyond the scope of this Article (as is the problem that Poland-through its imposed agent, the Soviet Union-also purported to waive all claims against Germany), a brief look at the wartime history of persecution is necessary in order to put that aspect of these peace treaties in context. That differentiated history, plus the fact that the Peace Treaties were signed in 1947, before the question of compensation for persecution was on any state's agenda, ${ }^{31}$ explain the limited nature but also the limited effect of this effort on resolving wartime claims.

provisions is exhaustively but not conclusively reviewed).

30. Treaty of Peace with Hungary, supra note 12, art. 27; Treaty of Peace with Romania, supra note 12 , art. 25 . These provisions covered seizures by the authorities of these two states, since only in the case of Hungary could there have been a German seizure of victim's properties and then only after the fall of the Horthy regime spring 1944. That the German government influenced the anti-Semitic persecution measures of those national regimes is another matter and becomes important in the implementation of post-1949 German legislation providing compensation to victims of persecution. This, too, is a matter beyond the scope of the present discussion.

31. Indeed, in the cited five-power Paris Agreement of June 1946, this was specifically excluded:

A. It is the unanimous and considered opinion of the Five Powers that in light of Paragraph $\mathrm{H}$ of Article 8 of the Paris Agreement on Reparation, the assets becoming available should be used not for the compensation of individual victims but for the rehabilitation and resettlement of persons in eligible classes ...

Paris Agreement, supra note 6, pmbl. 
The clearest situation is that of wartime Hungary. ${ }^{32}$ Anti-Semitic measures were already a feature of the Hungarian government of the 1930s; and although their sharper bite after the war was to some degree a reflection of German political pressure, those measures were on a continuum with that earlier time. But imprisonment, deportation, and extermination were not a part of that repression. Those tragedies were visited on Hungarian Jewry only after the fall of the national regime and the takeover of its functions by the German occupation forces. It is thus understandable that the Hungarian peace treaty would not face that question of compensation.

Romania presented yet a different situation, and the limitation to property restitution in its treaty was less justified. ${ }^{33}$ Roughly coinciding with the beginning of the war, its government permitted a genocidal assault on Romanian Jewry, resulting in the death of approximately 250,000 citizens or over one-third of this population. Once that bloodlust was slaked, the regime was satisfied with eliminating Jews from its economy and society, but did not, and unlike Hungary, was not forced to relinquish the remaining Jewish population to the Nazi exterminators. In this case, paradoxically, the German government was not charged with a compensation duty after the war. The fact that 1947 was too early for compensation to be on the agenda thus had no bearing on the nature of Romania's waiver of its and its subjects' claims against Germany.

Italy was in an intermediate position. ${ }^{34}$ The fascist prewar and early wartime legislation did contain the prevalent anti-Semitic economic and social elements. In addition, even before the fall of its regime in 1943 and the takeover of the northern regions by the Germans, some deportations with their fatal consequences did occur. On the whole, however, the Italian wartime regime did not fall either into the Romanian frenzy nor make the handover of any substantial part of the Jewish population to the Germans a considered policy. Indeed, so long as its military forces were in control of those areas of Greece, France, and Albania under its temporary occupation, their Jewish subjects were actively protected against German demands for their delivery. ${ }^{35}$ Most Italian Jews who were deported to the German concentration and extermination camps were seized after the fall of Mussolini. ${ }^{36}$ Under these circumstances, the arguable waiver of claims of and for its persecuted subjects can only be explained by the date of the peace treaty.

32. See Randolph Braham, The Politics of Genocide: The Holocaust in Hungary 880ff, $914 \mathrm{ff}, 971 \mathrm{ff}, 1019$ (1994).

33. In addition to the classic overview of both countries' experiences in 2 RAUL HILBERG, THE DESTRUCTION OF THE EUROPEAN JEWS 853ff [Hungary], 808ff [Romania] (3d ed. 2003), see THE Destruction of Romanian and UkRainian Jews During the ANTONESCu ERa (Randolph Braham ed., 1997); Irina Livezeanu, The Romanian Holocaust: Family Quarrels, 16 E. EUROPEAN POLITICS \& SOCIETIES 934 (2003).

34. Hilberg, supra note 33 , at $703 \mathrm{ff}$.

35. Id. at $690-94,748-750$.

36. Id. at $711-12$. 
The absence in the Italian case of a property-restitution requirement of the Hungarian and Romanian sort, however, needs other justification. That justification may lie in the facts (i.e., that little such confiscation took place), or in the possibility that Italy was treated with more consideration for political reasons - reasons that may well have included the early date of its surrender and switch to the Allied side.

In contrast to the Hungarian and Romanian narratives, Bulgaria's situation was a different story since the Holocaust did not rage there; therefore, the absence of restitution provisions is not surprising.

For the purposes of the present discussion, of course, the lesson of this review is that the seeds of a challenge to the historical distinction between state and private subjects of public international law were sown in this era.

With this overview completed, the mooted question of the exclusive nature of the Paris Reparations Agreement can be put into perspective. The ultimate beneficiary of the contingent commitment to treat the Paris allocation formula as the exclusive means and limit of reparations would have been the Federal Republic of Germany, but it did not come into existence until 1949. ${ }^{37}$ The immediate beneficiaries were the three Western Occupation Powers, especially the United States, which wished to avoid the competition of "excessive" reparations claims of their former Allies. ${ }^{38}$ Major claims of that sort would have clashed with these Powers' own expectation of repayment by the Germans of the increasingly significant occupation expenses incurred by them, in particular of the burden of keeping the German population fed and sheltered during the first three postwar years.

To recapitulate: The Potsdam Agreement allocated to the Soviet Union twenty-five percent of those West German industrial assets the four Occupying Powers might claim as reparations. The remaining seventy-five percent was available for allocation among all Western Allies pursuant to the percentage scheme agreed to at Paris - but the important point was that the absolute amount of that theoretical asset was within the discretion of the Allied Control Council to determine. Given the de facto acceptance of Soviet and Western spheres of influences, the Western Occupation Powers had the ultimate decision-making power in dividing up Germany industrial assets. With the increasing influence of the Cold War and the increasing drumbeat of respect for private property heard

37. The technical legal question of whether the Federal Republic after 1949 could claim the benefit of this 1946 commitment exercised the minds of German legal scholars from that date on. See, Hans Baade, Die Behandlung des deutschen Privatvermögens in den Vereinigten Staaten nach dem ersten und zweiten Weltkrieg, in DER SCHUTZ DES PRIVATEN EIGENTUMS IM AUSLANDFESTSCHRIFT FUR HERMANN JANSSEN, supra note 37, at 11; ALBRECHT RANDELZHOFER \& OLIVER DÖRR, ENTSCHÄDIGUNG FÜR ZWANGSARBEIT? (1994) for early, and late, treatments of this issue. Indeed, the issue played a role in the U.S. litigation that in turn was a major factor in bringing about the creation of the German Foundation described in supra note *.

38. See Buxbaum, Legal History, supra note 1, at 323, 327 n.32. 
in the United Kingdom and the United States, ${ }^{39}$ those Powers kept reducing the overall amount allocable to Western Allies until, with the Petersberg Protocol of November $1949,{ }^{40}$ they settled on an amount that was only a fraction of what the other Allies had expected when they concluded the Paris negotiations.

For the next five years - but only for the next five years - neither the 1946 Paris Agreement nor the 1947 Peace Treaties generated significant conflicts between state and private claimants to German and Axis assets. Conflicts among the Allied states continued over the issue of property characterization (i.e., over the broad versus narrow characterization of specifically restitutable property), but these were largely resolved by sidebar bilateral agreements. ${ }^{41}$ Allied nationals who suffered specific war damage ${ }^{42}$ even benefited - though only to a small extent-from war-claims legislation enacted by their respective governments. This category of Allied nationals, as distinguished from victims of persecution, ranged from prisoners of war and civilian detainees to firms losing business opportunities because of the war. The less the recovery the greater the occasion for domestic disputes between these states and their subjects, but this possibility did not give rise at that time to direct competing claims by these subjects against the former Axis states. On the contrary, as illustrated by the U.S. example, such conflicts as arose were largely those between German and other Axis private parties challenging the freezing and vesting of their property under the U.S. Trading With the Enemy $\mathrm{Act}^{43}$ on various grounds. These grounds included both direct due process challenges to the takings as such and procedural challenges to their limited right to contest the enemy characterization. ${ }^{44}$

39. This is a point worth emphasizing; see references supra, note 22.

40. The Protocol is summarized in Press Release, Dep't of State, No. 919 (Nov. 24, 1949).

41. These agreements either concerned conflicting claims to physical property held by the Allied Occupation Powers in Germany, or claims concerning frozen assets, typically financial assets such as shares, held under conflicting wartime freezing or vesting orders. See in particular the multilateral Agreement relating to the resolution of conflicting claims to German enemy assets, Dec. 5, 1947, T.I.A.S. No. 2230; but bilateral implementing arrangements also were needed. An example is the sub-ministerial Executive Agreement (literally, "Understanding") between the U.S. and Norway, "Conflicting Claims to Enemy Property," June 21, 1952, T.I.A.S. No. 2980, relating to assets frozen under both Norwegian and U.S. wartime legislation because of the presumed enemy status of their beneficial owners.

42. As distinguished from victims of persecution.

43. Trading With the Enemy Act, 40 Stat. 411 (1917) (codified as amended at 50 U.S.C. 1 et seq.).

44. The summary nature of U.S. authorities' treatment of German owners' postwar claims for property return is clear from the leading cases. Standing to allege the absence of "enemy status," a necessary prerequisite to challenging a confiscation, was granted at the pleading level: Clark v. Uebersee Finanz-Korporation v. McGrath, 343 U.S. 205 (1952) (the Opel case); Clark v. Uebersee Finanz-Korporation, 332 U.S. 480 (1947). At the substantive level, however, "[t]here [was] no constitutional prohibition against confiscation of enemy properties," United States v. Chemical Foundation, Inc., 272 U.S. 1, 11 (1926). In consequence, the denial of procedural rights to German nationals to appeal detrimental agency determinations was upheld in Schilling v. Rogers, 363 U.S. 666 (1960). 
III.

\section{The SWISS CASE: Private Property AND LoOted Gold}

The next issue for consideration is the effort to identify and collect German public and private assets held in neutral countries, assets that were to be used both in partial satisfaction of the reparations claims of the Western Allies and to stock the proposed fund of $\$ 25,000,000$ for the support of the Displaced Person population. The 1997-1998 U.S. State Department studies of those efforts, while necessarily hurried and incomplete, provide sufficient information to permit reference to them in lieu of full discussion here. ${ }^{45}$ Since the primus inter pares of neutral countries was Switzerland, an evaluation of the results of the efforts involving Switzerland - limited to the larger thematic focus of this Article-is appropriate at this point even if based largely on secondary sources. ${ }^{46}$ As explained below, Switzerland has a recent history of restitution obligations that are directly related to the themes of this study. ${ }^{47}$

The Swiss role during World War II, and therefore the potential justification of any possible claims of the Allies against Switzerland, had two aspects that were relevant to the reparations issues. First, gold stocks of occupied Allied countries looted by German occupation forces were sold by the Third Reich to Swiss banks to obtain the Swiss currency that in turn was a critical factor in German purchases of essential war material from a number of other neutral countries. Second, German individuals and companies owned Swiss properties and financial assets, and also hid financial assets through the use of Swiss nominees, including assets evidencing ownership of ostensibly non-German firms in a variety of Allied and neutral countries.

45. The two central studies are State Dep't Pub. 10468, U.S. and Allied Efforts To Recover and Restore Gold and Other Assets Stolen or Hidden by Germany During World War II (1997) [hereinafter USDS-I], and State Dep't Pub. 10557, U.S. and Allied Wartime and Postwar Relations and Negotiations With Argentina, Portugal, Spain, Sweden, and Turkey on Looted Gold and German External Assets and U.S. Concerns About the Fate of the Wartime Ustasha Treasury (1998) [hereinafter USDS-II].

46. Particularly useful in this connection are Linus vON CASTELmur, SCHWEIZERISCHALLIIERTE FinANZBEZIEHUNGEN IM ÜBERGANG VOM ZWEITEN WELTKRIEG ZUM KALTEN KRIEG (2d ed. 1997), and the principal report and associated studies of the Swiss Independent Committee of Experts ("the Bergier Commission"), created by the Swiss Government to provide a contemporary review of this history. Swiss Independent Commission of Experts, Second World War (ICE) (2002), available at $\mathrm{http}: / / \mathrm{www} . u e k . c h / \mathrm{en} / \mathrm{index} . \mathrm{htm}$. These items are cited below as appropriate.

The Swedish wartime history of gold purchases (little more than one percent of the Swiss ones), and the postwar treatment of Allied claims to German private property found there are the subject of a study by COMMISSION ON JEWISH ASSETS IN SWEDEN AT THE TIME OF THE SECOND WORLD WAR, THE NAZIGOLD AND THE SWEDISH RIKSBANK (1998), supplemented by same, FinAL REPORT (1999).

47. The class action against the Swiss banks for their treatment of Holocaust-era bank accounts (In re Holocaust Victim Assets, 105 F. Supp. 2d 139 (E.D.N.Y. 2000)) and its sequels are described and evaluated in Roger Alford, The Claims Resolution Tribunal and Holocaust Claims Against Swiss Banks, 20 BERKELEY J. INT'L L. 250 (2002). 
Early in the war, the Allies, cognizant of these possibilities, froze Swiss assets in their own countries ${ }^{48}$ and warned Swiss and other Neutrals' authorities about these two types of transactions. Later in the course of the war-in January of 1943 and again in February of 1944 - the Allies formally announced their intention to undo any illegitimate transactions of either type. ${ }^{49}$ The Paris Reparations Agreement called for the identification, seizure, and return of looted gold — both public monetary and (if identifiable) private gold — and its transfer either to its original owners or into a fund for proportional reallocation to the eligible Allied countries. ${ }^{50}$ Since Swiss wartime transactions in German gold accounted for over three-quarters of all German gold transactions, ${ }^{51}$ and since these gold holdings were thought at the time to be a principal and certainly an early component of reparations, the post-Paris interest of all Western Allies in this aspect of the planned approaches to Switzerland and other Neutralsespecially as to the monetary gold-was intense.

The interest in German private-sector financial assets (including in those nominally held by Swiss subjects) came to some degree from the same reparations focus, though the Swiss portion of German overseas assets was less prominent. The major Allied Powers' interest in those assets, at least in the immediate postwar years, in large part was based (or said to be based) on the fear of a German resurgence and the concomitant need for control over

48. In the United States this was a general program, designed in part to protect the U.S.located assets of occupied countries and their subjects from German seizure and in part (after United States entry into the war) to hinder German war efforts. In lieu of other primary statutory, regulatory, and judicial citations to the earlier wartime period, see MARTIN DOMKE, THE CONTROL OF ALIEN PROPERTY 174-75 (1943; Supp. 1947). It is worth noting that at the start of this program even the property of victims of the German Reich, if themselves German subjects, were caught in this program; the release of these assets proceeded only over time and on a case-by-case basis.

49. See Inter-Allied Declaration Against Acts of Dispossession Committed in Territories Under Enemy Occupation or Control, January 5, 1943, in 1 FOREIGN RELATIONS OF THE UNITED STATES 439, 443-444 (1943) (generally called "Inter-Allied Declaration Against Acts of Dispossession"); Concern of the United States Over Enemy Attempts to Secrete Funds or Other Assets in Neutral Countries: Inception of the Safe-Haven Program, February 22, 1944, in II FOREIGN RELATIONS OF THE UNITED StATES 213, 213-14 (1944) (generally called “Allied Gold Declaration") (putting neutral countries on inquiry notice concerning the source of their purchased German gold). For a brief review of their origin and scope, see USDS-I, supra note 45, at 6-7, 9-10. Their texts are analyzed and their deficiencies criticized in Jacob Robinson, Transfer of Property in Enemy Occupied Territory, 39 AM. J. INT'L L. 216 (1945).

50. In the case of state (not private) claims, gold was considered fungible and thus appropriately pooled and distributed to all Western Allies pursuant to the Paris Reparations Agreement formula, without regard for the possibility that bar and ingot markings might prove otherwise as to their original provenance. See the fuller discussion of this sensitive issue infra Part IV.

51. See, from two different starting points, UNABHÄNGIGE EXPERTENKOMMISSION SCHWEIZZWEITER WELTKRIEG, DIE SCHWEIZ UND DIE GOLDTRANSAKTIONEN IM ZWEITEN WELTKRIEG 78 (2002); JOHANNES BÄHR, DER GOLdHANDEl DER DRESDNER BANK IM ZWEITEN WELTKRIEG (1999). See also Jonathan Steinberg, The Deutsche Bank And Its Gold Transactions DURING THE SECOND WORLD WAR (1999). 
productive resources capable of fueling that resurgence. ${ }^{52}$ While understandable during the war, this concern also seemed legitimate and serious at least during the first postwar year and remained a strategic point of some-though diminishing-significance in the Swiss negotiations described in the next section. ${ }^{53}$ Soon, however, this concern took a backseat to the straightforward desire to capture those assets for additional reparation purposes - and thereby suffered the same loss of legitimacy suffered by all efforts to seize the private property of former enemy subjects.

Moral pressure to participate in the costs of European reconstruction, ${ }^{54}$ combined with the Swiss interest to regain its subjects' war-frozen properties in Allied hands, led Switzerland to agree to negotiate with the Allies over the implementation of the Paris Agreement. Those first negotiations began in the spring of 1946 and culminated in the Washington Accord of that summer. The negotiations were bitter and did not bode well for the future, when the difficult process of implementation of the Accord would have to be faced. ${ }^{55}$ The effort to procure the return of or compensation for monetary gold looted from occupied nations' central banks was hindered by Swiss efforts to refute the claim that the Swiss National Bank had known or at least had inquiry notice of the provenance of that gold when it accepted it from the Third Reich. ${ }^{56}$ The issue of the seizure of privately owned German external assets held in Switzerland was complicated by the Swiss' instrumental use of property rights to challenge the Allied claim to the private property of German nationals, including that of German corporations and other legal entities. ${ }^{57}$

52. This was the reason for the so-called "Safehaven Program" that the U.S. urged its other Allies, especially the U.K., to launch. A quotation from the first internal review by the U.S. Department of State in 1944 [the "Klaus Report"], as cited in USDS-I, supra note 45, at 16-17, succinctly describes the issue: "In its most important aspects [Safehaven] is to prevent the use of neutral countries as bases for maintaining the assets, skills and research necessary for the conversion of Germany to a war basis at an appropriate future date."

53. Id. at $20 \mathrm{ff}$.

54. This issue of "moral pressure" was the subject of considerable debate within the U.S. Administration at the end of the war. The World War II Neutrals consistently rejected any legal argument that German property, in particular private property, could be claimed by the victors. After debates within U.S. circles and between them and British circles, a proposal by Seymour Rubin (then a Treasury Department delegate and for decades, until his death in 2002, a major figure in these postwar events) that the claim was more appropriately put in moral terms, was generally accepted among the Western Allies and at least in principle by the Neutrals.

55. See generally VON CASTELMUR, supra note 46.

56. Whether the Swiss banks, especially the Swiss National Bank (that in time became the only authorized purchaser) knew the gold was looted became an issue during the Allies' postwar negotiation with the Swiss for the return of gold. See VON CASTELMUR, supra note 46, at 61. The Swiss Independent Committee of Experts ("Bergier Commission") now has published an exhaustive monograph on this matter that is devastating in its criticism of the Swiss National Bank leadership and its claim of good faith. See UNABHÄNGIGE EXPERTENKOMMISSION SCHWEIZ, supra note 44, passim and in its summary at 311 .

57. Of course, this itself was only a part of the larger debate over the legitimacy of Allied claims to privately owned German assets, even within Germany. See supra note 19. 
This external-asset situation was nominally resolved when the three Allied negotiators accepted the requirement that either the Swiss or a future German government would compensate the prior owners. This was, predictably, of little value as neither the compensation formula nor the all-important Swiss-German exchange rate formula was resolved by the Accord. The Swiss element of this duty to compensate private owners of these properties was partially resolved with the agreement to split the proceeds of the Swiss sale of Swiss-controlled German assets between Switzerland and the Allies. ${ }^{58}$ The monetary gold issue was resolved by a compromise as to the amount of gold Switzerland would be obliged to provide to the gold pool in satisfaction of Allied claims. However, neither that transfer-made almost immediately-nor the later, much-delayed and much-contested transfer ${ }^{59}$ of the proceeds of the Swiss-held external German assets provided the other signatories to the Paris Convention with nearly the amount they had originally expected from these two sources.

Under those circumstances, which were foreseeable in 1946, it is not surprising that the first Washington Accord could not settle the question of preclusion of further claims against Switzerland by the Western Allies. So far as the monetary gold transfer issue was concerned, the Allied signatories did give the equivalent of an accord and satisfaction, waiving on behalf of themselves and of all signatories of the Paris Reparations Agreement any further claims to gold obtained by Switzerland from Germany during the war. ${ }^{60}$ There was less to the Agreement than meets the eye, however. In a separate letter, the French delegate asserted that this waiver would not apply to monetary gold seized by the Germans, transferred to and held by the Swiss as depositaries, and then sold by the Germans to other parties. ${ }^{61}$ The waiver also did not prevent the Dutch government from raising a claim against the Swiss shortly thereafter on the basis

58. Agreement between the United Kingdom, France, the United States, and Switzerland, concerning German property in Switzerland, Aug. 28, 1952, 175 U.N.T.S. 69.

59. "Much-delayed" because, as discussed immediately below, the first Accord of 1946 could not be implemented.

60. Accord relating to the liquidation of German property in Switzerland, Annex, art. II(2), June 27, 1946, 13 U.S.T. 1118.

61. Letter No. 14, appended to the Accord, cited by VON CASTELMUR, supra note 46, at 94 (von Castelmur does not reproduce these letters but instead cites to the Swiss Federal Archive (Bundesarchiv Bern, 2801, 1968/84, 32)). The letter discusses the notorious problem of the Belgian monetary gold, which Belgium had transferred to France on the eve of occupation. Moved to Senegal as a precautionary measure, it was then nonetheless seized by the Germans, possibly with the collaboration of French Vichy officials - see Arthur L. Smith, Jr., Questions Concerning the Looted Nazi Gold Controversy, 20 CARDOZO L. REV. 483, 485-86 (1998) - surreptitiously airlifted to Germany and then transferred to Switzerland for deposit. According to VON CASTELMUR, supra note 46 , at $94 \mathrm{n.328}$, the Swiss delegation implicitly accepted this reservation, at least to the degree of giving the French an accounting of that deposit, a step they had rejected during the negotiations when the issue was their good faith and lack of actual knowledge of the source of that deposit.

The Belgian gold transfer had its own postwar sequel in litigation between Belgium and France over the allocation of gold from the gold pool marshaled for distribution by the Tripartite Commission. See discussion in Part IV infra. 
of newly discovered evidence concerning the transfer of Dutch monetary gold reserves to Switzerland, though the Swiss rejected the demand to reopen the question of their negotiated payment. ${ }^{62}$ And, of course, the waiver was subject to the general argument - often and again recently made - that it did not preclude individual claims for identifiable non-monetary gold. This issue is discussed in more detail later since it is more relevant to the "conflicting privatepublic claims" issue that is the basis of this narrative. ${ }^{63}$

As for the registration, liquidation, and distribution of the proceeds of the sale of the private German external assets in Switzerland, and putting aside the debate over its legitimacy, ${ }^{64}$ the circumstances of that process did not permit any concept of exclusivity and preclusion to be raised explicitly. The equivalent of a waiver, however, was programmed into the procedure that was adopted: The official Swiss Federal Accounting Office (Verrechnungsstelle) was charged with the duty of registering those assets, and was subject to consultation with and oversight by a Mixed Commission on which the Allies were represented. Swiss domestic legislation then took care of the problem of any later-discovered but previously unregistered assets in a way that was satisfactory to the Allies. ${ }^{65}$

It can be argued that the issues left unsettled by the 1946 negotiations, which became the barrier to implementation of the Accord, were only surface manifestations of an important underlying disagreement about the sanctity of private property - even enemy property - a disagreement which the illusory agreement to compensate its former owners could not mask. ${ }^{66}$ From the outset, not only Swiss but German, British, and even American commentators protested

62. VON CASTELMUR, supra note 46, at 118; Stuart E. Eizenstat, et al., U.S. and Allied Efforts To Recover and Restore Gold and Other Assets Stolen or Hidden by Germany During World War II (May 1997), available at http://www.ushmm.org/assets/state/.

63. Part V infra.

64. See infra note 69 and accompanying text.

65. A brief description is given by VON CASTELMUR, supra note 46, at $158 \mathrm{ff}$. A doctoral dissertation by a member of the Verrechnungsstelle is the best source for a full description of the registration and liquidation process, the values claimed, the amounts received on liquidation, andespecially interesting - the proportions represented by corporate assets (and financial assets) and individual assets such as bank accounts respectively. See generally HANS W. LeUZINGER, DIE DEUTSCHEN VERMÖGENSWERTE IN DER SCHWEIZ UND IHRE STATISTISCHE ERFASSUNG (1960).

The notorious Interhandel situation does not fall within this context. The Interhandel situation involved a Swiss firm (Interhandel), which held securities evidencing ownership of U.S.situated corporate assets. The U.S. claimed that Interhandel was a front for IG Farben, a German holding company. It has long deserved a separate investigation, one that now has been provided by a Swiss historian. See MARIO KÖNIG, INTERHANDEL: DIE SCHWEIZERISCHE HOLDING DER IG FARBEN UND iHRE METAMORPHOSEN-EINE AFFäRE UM EIgENTUM UND INTERESSEN, 1910-1999 (2001), one of the studies commissioned by the Bergier Commission.

66. It has been suggested that underlying this concern with property rights was the importance to the Swiss financial sector, and thus to the government, of the inviolability of the Swiss finance sector as a haven for foreign deposits. In one sense, that sector's insistence on this inviolability is understandable and unsurprising. How far that sector influenced the government, which had to balance its need to restore Switzerland in the postwar Allied-dominated world against its domestic economic interests is a topic for inquiry by historians and political scientists. 
the U.S. position on the seizure of privately owned (including corporate) enemy assets. In Switzerland, that position from the beginning was characterized as the unprincipled exercise of the victors' power. ${ }^{67}$ This was not surprising. ${ }^{68}$ The United States had previous experience with the young Soviet Union and Mexican appropriations of U.S. investments within recent memory, and was at this very time facing expropriation activities by the Socialist states of Central and Eastern Europe. The legitimate distinction between expropriation of aliens' interests and the confiscation of one's own subjects' interests ${ }^{69}$ was not, in the context of the Allies' role as the state authority in the defeated Germany, one that could withstand much pressure, and that quite apart from the looming Cold War. $^{70}$

67. The clearest and typically critical expression of this basis of the Allied action at the time is that of a famous U.K. practitioner-academic, himself a German émigré: F. A. Mann, German Property in Switzerland, 23 BRITISH Y.B. INT'L L. 354, 356 No. 5 (1946):

The Allies ... claimed title in their capacity as sovereigns in Germany. They stood in the shoes of a German Government. [I]t is essential to see this clearly and to eliminate any confusion which may arise from ... [this] peculiar position ....

There cannot be any doubt that German municipal legislation confiscating German property in Switzerland would have been held by Swiss courts to be opposed to Swiss public order and would, consequently, not have been recognized [citing, interestingly enough, United States v. Pink, 315 U.S. 203 (1942)].

Incidentally but not trivially, Mann's view reveals the difference the U.S. Act of State doctrine makes in this analysis. See its slightly later expression in Banco Nacional de Cuba v. Sabbatino, 376 U.S. 398 (1964) in the much stronger case of the expropriation not of one's own nationals' but of aliens' property.

68. One anomaly, however, deserves brief mention. The Swiss government itself in effect confiscated the equivalent of the increase in gold value created at the time of its 1936 devaluation of the Swiss franc by the expedient of declaring that monetary gain a "profit", which could be recaptured at least from the Swiss National Bank under domestic legislation if not even from private holders of gold. See A.H. Engeli, Die Beteiligung der Schweizerischen Nationalbank an den nach Washingtoner Abkommen zu bezahlenden 250 Millionen, 43 SJZ 149-50 (1947). In fact, as this title suggests, the last remnant of that "profit" was used by the Swiss government to complete its obligation to turn over the monetary gold called for in the Accord.

69. A nuanced review of the subject-alien distinction in the specific context of private enemy property is found in CHRISTIAN DOMINICÉ, LA NOTION DU CARACTÈRE ENNEMI DES BIENS PRIVÉES DANS LA GUERRE SUR TERRE (1961).

70. Edwin M. Borchard, The Diplomatic Protection of Citizens Abroad 251 (1927). From among the legion of German and Swiss publications on this subject of the confiscation of the private property of the enemy, see in particular the contemporaneous writings of GERHARD GRAF, Die LiQuidation DER DEUTSCHEN VERMÖGENSWERTE IN DER SCHWEIZ (1949), KARL G. SEELIGER, DAS AUSLÄNDISCHE PRIVATEIGENTUM IN DER SCHWEIZ (1949), and Rudolf Moser, Das Washingtoner Abkommen in schweizerischer und deutscher Beleuchtung, in STAAT UND WIRTSCHAFT: BEITRÄGE ZUM PROBLEM DER EINWIRKUNG DES STAATES AUF DIE WIRTSCHAFTFESTSCHRIFT FUR HANS NAWIASKY 109 (1950).

On the related and at the time practically important problem of the effect of the 1946 Washington Accord on private-law transactions involving the German assets marshaled in Switzerland, see Walther Hug, Sperre und Liquidation deutscherVermögenswerte und ihre Wirkungen auf die privaten Rechtsverhältnisse, in STAAT UND WIRTSCHAFT: BEITRÄGE ZUM PROBLEM DER EINWIRKUNG DES STAATES AUF DIE WIRTSCHAFT-FESTSCHRIFT FUR HANS NAWIASKY 261 (1950). Interestingly, given the federal nature of the Swiss Confederation, this 
Three separate issues were involved in this complex and contentious debate. The first concerned the legal status of the Allies' exercise of lawmaking power in Germany. On the whole, while some doubts were expressed on this matter even by one or two Neutral Powers faced with Allied pressure to cooperate $^{71}$ (not to mention the objections of most German commentators ${ }^{72}$ ), these doubts could not withstand the facts on the ground. The second issue concerned the intended scope of the various Allied laws and proclamations. ${ }^{73}$ In part this was a matter of statutory construction of the Occupation legislation-of whether seizure of German assets included financial assets representing German ownership of foreign properties. ${ }^{74}$ In part, this issue reflected an early and illusory expectation of the Allies that they could satisfy much of their reparation claims from the state- and state agency-owned assets as well as from those held by a class of complicit individuals that was yet to be defined..$^{75}$ The third issue, however, was the central difficulty: Would other states, especially the Neutrals, recognize confiscatory decrees that would have effect in their countries, either indirectly through the confiscation of German financial assets evidencing ownership of property there, or directly through the registration of new titles? ${ }^{76}$

problem is a matter of the federal division of legislative competence in Swiss public law between the federal government and the cantons. See generally FrITZ Fleiner \& Z. GiacometTI, SCHWEIZERISCHES BUNDESSTAATSRECHT Sec. 79 (810ff) (1949) - a problem not unknown to the United States treatment of the conflict between treaty law and states' rights.

71. The pro forma Swiss objection based on this ground is described in VON CASTELMUR, supra note 46, at 104-19. A brief review of other neutrals' positions on this issue is provided by Otto Böhmer, Grenzen der Auswirkung des besatzungsrechtlichen Beschlagnahmerechts, in DEUTSCHLAND AUF DEUTSCHES AUSLANDSVERMÖGEN-FESTSCHRIFT FUR HERMANN JANSSEN 4243 (1958).

72. Böhmer, supra note 71 , at 51-54.

73. Specifically, based on Proclamation No. 2 of the Four-Power Control Council and the subsequent Council Law No. 5 of Oct. 31, 1945, in 1 OfFiCial GaZETTE CONTROL COUNCIL FOR Germany 8 (Oct. 29, 1945) 8, and 2 Official Gazette Control Council For Germany 27 (Nov. 30, 1945), both in turn based on the Allied Powers June 5, 1945 "Declaration Regarding Defeat of Germany and the Assumption of Supreme Authority with Respect to Germany ..." available at $\mathrm{http}: / /$ avalon.law.yale.edu/wwii/ger01.asp.

Its Preamble stated:

The Governments of the United States of America, the Union of Soviet Socialist Republics and the United Kingdom, and the Provisional Government of the French Republic, hereby assume supreme authority with respect to Germany, including all the powers possessed by the German Government, the High Command and any state, municipal, or local government or authority. The assumption, for the purposes stated above, of the said authority and powers does not affect the annexation of Germany.

74. These issues are discussed in Böhmer, supra note 71.

75. See Paris Agreement, supra note 3.

76. The position of the signatories of the 1946 Paris Reparations Agreement on this point was complicated by the debatable nature of Part I, Article 6A, which could be interpreted to bar each from returning privately owned German assets found in its territory to the former owners. Whether this was a provisional measure to aid the IARA in its work or a final disposition was subject to debate. Cf. Henry de Vries, The International Responsibility of the United States for Vested German Assets, 51 AM. J. INT'L L. 1 (1957), with Ulrich Scheuner, Zur Auslegung des Interalliierten 
These matters hampered negotiations with the Neutrals and in the end led to illusory compromises on these matters. So far as Switzerland was concerned, since the Washington Accord contained the promise of compensation for these liquidations and distributions, ${ }^{77}$ the larger issues of principle were quickly subsumed within the smaller issues of the modalities of that payment. ${ }^{78}$ These payments were sufficiently contentious, however, especially in the context of the eroding U.S. and U.K. support for draconian confiscation measures, that the Accord could not be honored. Only with a return to the negotiation table and the conclusion of the far less stringent second Washington Accord of 1952, did this episode in the Allies' relationship with the European Neutrals come to a whimper of a conclusion. 79

IV.

\section{MONETARY GOLD}

This story, as mentioned, is only a part, though a large part, of the general situation representing the third element of the post-Paris Treaty situation: the recapture and reallocation of monetary gold among those of the Allies occupied during the war. ${ }^{80}$ The Paris Agreement created a Tripartite Commission for

Reparationsabkommen vom 14.1.1946, in DER SCHUTZ DES PRIVATEN EIGENTUMS IM AUSLANDFESTSCHRIFT FUR HERMANN JANSSEN, supra note 37, at 135.

77. Payment, it should be noted, not by the United States, but by the new Federal Republic of Germany. This had a two-stage sequel: two 1952 treaties between Switzerland and Germany (see Agreement Between the Federal Republic of Germany and the Swiss Confederation concerning the equalization of burdens, Aug. 26, 1953, II BGB1 15), and Switzerland and France/U.K./U.S. (see Agreement between the United States, France and the United Kingdom, and Switzerland, Concerning German Property in Switzerland, Aug. 28, 1952, 175 U.N.T.S. 69). These treaties intended to regulate the respective payments by Germany and German property claimants (of Swisslocated property) that would honor the kited check issued by the Washington Accord. Not surprisingly, constitutional litigation then ensued in the Federal Republic between those claimants and the German government over the obligation imposed by German law on the claimants to participate on an equalization-of-burdens basis in the payments to Switzerland. See Richard Buxbaum, Equalization of Burdens, in II FESTSCHRIFT FUR ERIK JAYME 1051, 1055-56 (2004). $140 \mathrm{ff}$

78. The following is based to a considerable extent on VON CASTELMUR, supra note 46, at

79. See Agreement between the United States, France and the United Kingdom, and Switzerland, Concerning German Property in Switzerland, Aug. 28, 1952, 175 U.N.T.S. 69. The domestic U.S. analogue to these issues - the liquidation and distribution of German corporate assets and individual ownership interests - is related to the foregoing only in the sense that those recoupments substituted for U.S. reparations claims in the international context; i.e., in the context of the Paris Agreement. This is the story of the Alien Property Custodian Office. See the full discussion in Domke, supra note 42, at 174-78.

80. Non-monetary gold was composed of two parts. The first was individual victims' gold, ranging from gold objects confiscated from Jews after forced registration in Germany and occupied countries to the gold extracted from the teeth of the exterminated victims of the gas chambers. These items fell into the category of assets to be pooled under the Paris Agreement's Part I Article 8 procedure, supra Part I. The second was all other privately owned gold, ranging from numismatic items to industrial-use gold. The controversies surrounding its appropriate (definitional) separation from monetary gold were significant at the time. See infra note 76 and accompanying text. 
Monetary Gold to implement these obligations. It was formally constituted in September of 1946 and, amazingly, was not decommissioned until late 2000 after finishing its distributions in 1996. So far as the actual recovery of this gold is concerned, ${ }^{81}$ it depended largely on the Allied negotiations with the Neutrals, such as the already described marathon with the Swiss. Of course not all of this gold was recoverable, but contemporaneous sources then, and historians now, estimate that roughly sixty-five percent of all monetary gold looted by the German occupiers was recovered. ${ }^{82}$ This aspect of the early effort to implement the relevant provisions of the Paris Agreement has been reviewed by a number of national agencies since the issue resurfaced as a part of the focus on these events in the 1990s. ${ }^{83}$

Since it is not the purpose of this Article to detail the specific outcome of these efforts but to place them in the context of the evolution of the international law norms of reparation from purely intergovernmental to wider ranges of international relations, reference to the more comprehensive of those studies will suffice here. ${ }^{84}$ Only two specific elements of this search for gold deserve brief separate mention: conflicting private and governmental claims to gold, based on the contested broad characterization by the Tripartite Commission of "monetary gold;" and conflicting survivors' and organizational claims to victims' gold.

One major element of ongoing dispute was the claim of private parties that gold ostensibly held as part of a nation's monetary reserves in fact belonged to these parties and had only been stored with Central Bank or Finance authorities or, in the more blatant cases, merely registered with these authorities. This occupied both the Commission and the courts during the first decade or two after 1946. Exemplary of this issue is a case well known in the 1950s, the Dollfus-Mieg litigation, ${ }^{85}$ although the matter has arisen occasionally even in

While victims' gold comprised a minuscule proportion of all gold (UNABHÄNGIGE EXPERTENKOMMISSION SCHWEIZ, supra note 44, at 66 (providing the most detailed current account of these categories, not only of the part shipped to Switzerland)), the circumstances of its creation understandably have been in the forefront of public attention during this past decade. It is to the credit of the Western Allies that it was the subject of equally intense concern during the first, pre1949 period of asset recovery.

81. In fact, its single largest haul was the gold discovered by U.S. troops in Thuringia at the end of the war, the so-called Merkers cache that then was stored and inventoried in Frankfurt. See the description of these events in ARTHUR L. SMITH, JR., HitLER's GOLD: THE STORY OF THE NAZI WAR LOOT 85-88 (1989); and the earlier review in Elizabeth B. White, The Disposition of SS-looted Gold During and After World War II, 14 AM. J. INT'L L. 213 (1955). The story now has been extensively revisited in USDS-I, supra note 45 , at xxxi-ii, $151 \mathrm{ff}$.

82. See the discussion of these efforts in USDS-II, supra note 38 , at 175 . A brief summary of the assets found in and claimed from each of the Neutrals is given in Wilhelm Cornides \& Hermann Volle, Der Abschluss der Westdeutschen Reparationsleistungen, 8 EUROPA-ARCHIV 3281-82 (1953), as cited in Dolzer, supra note 4, at 320 n.77.

83. Paris Agreement, supra note 3, art. III; Eizenstat, supra note 62.

84. Again from the Bergier Commission brief. See generally UNABHÄNGIGE EXPERTENKOMMISSION SCHWEIZ, supra note 44.

85. Dollfus Mieg \& Compagnie S.A. v. Bank of England, (1952) 1 All E.R. 572 (1952). The 
recent times. ${ }^{86}$ Much of this type of dispute came about because the Commission decided in 1947 that any gold with markings that evidenced possession by a central bank was "monetary gold" rather than privately originating gold. ${ }^{87}$ With this definition, it avoided possibly legitimate restitution claims of private parties in order to maximize the amount of gold available for state reparations under the allocation formula of the Paris Agreement. For understandable reasons, none of the involved governments had a motive to challenge this approach. Their own disputes were over claims that identifiable monetary gold should be returned as part of a privileged restitution program rather than shared as part of an allocation of reparations; any action that increased the size of this "gold pot" was welcome. ${ }^{88}$

The other major intergovernmental issue was a byproduct of the Cold War. Albania and Czechoslovakia of course had been part of the Western camp at the time of the Paris Reparations Agreement and were entitled to their allocated share. ${ }^{89}$ Because the United States had unresolved claims against each country

plaintiff-company's claim to its identifiable gold bars, that had been stored in France, seized by German authorities, found in the Merkers cache, and transferred to the Bank of England as bailee/custodian for the Tripartite Commission, was rejected on the jurisdictional ground that the foreign sovereign immunity of the U.S. and France, as members of the Commission, also extended to the Bank as bailee.

86. See, e.g., Chytil v. Powell, 15 Fed. Appx. 515 (9th Cir. 2001), which, though this is not clear from the decision, concerned plaintiff's claim to gold bars seized during the German occupation of Czechoslovakia, in turn found by U.S. military authorities and shipped to the United States, and then returned to Czechoslovakia at the time of the 1981 mutual claims settlement. A final round played out in the work of the Property Commission under the German Foundation for Remembrance, Responsibility, and the Future, supra note *. Some of the claims filed with it asserted the seizure of gold of this sort by German occupation forces.

87. See its questionnaire of June 1947 to claimant states requesting claim details, in which the Commission defined monetary gold as "all gold... carried as part of the claimant country's monetary reserve either in the accounts of the claimant Government itself or in the accounts of the claimant country's central bank or other monetary authority at home or abroad." JAMES A. LEACH, THE EIZENSTAT REPORT AND RELATED ISSUES CONCERNING UNITED STATES AND ALLIED EFForTS TO Restore GOLD AND OtHer AsSETS LOOTED By NAZIS DuRING WWII 223 (1997). According to FOREIGN \& COMMONWEALTH OFFICE, Historians IN LiBRARY AND RECORDS DEPARTMENT, NAZI GOLD: INFORMATION FROM the BRITISH ARCHIVES, History NOTES NO. 11 (1996), this consciously avoided the reality that much gold nominally held by a central bank had been held for the account of private parties. That conclusion is well supported by original archival records (on file with author).

88. This was the issue in the Franco-Belgian dispute; here, too, the earlier characterization of the entire reparations process as a type of bankruptcy administration, with its analogies of secured and unsecured, priority and non-priority claims, is apparent. See Smith, supra note 81, at 158.

89. Albania first had to prevail against the claim of Italy to the former's monetary gold, which always had been held in Italy because of the unsettled climate in post-World War I Albania, and which had originally been built up under circumstances allowing Italy to argue that it was not a state-owned reserve. This issue was resolved in Albania's favor in an arbitration fact-finding proceeding invoked by the Tripartite Commission under its procedural rules. See Arbitral Advice of Sole Arbitrator G. Sauser-Hall, Feb. 20, 1953, 20 I.L.R. 441 (1953). By then, of course, Albania was the fortress-outpost of the Soviet sphere of influence; hence the standoff of four decades before the "Advice" was honored. 
for the expropriation of its subjects' property during the postwar Socialist regime period, it used its position on the Tripartite Commission to prevent disbursement of those shares until agreement was reached on those matters. Agreement was not reached until 1981 in the case of Czechoslovakia and until 1995 in the case of Albania. ${ }^{90}$ As a result, the Commission did not lay down its mandate and obtain its discharge until then.

$\mathrm{V}$.

\section{VICTIMS' GOLD}

The issue of victims' gold, as mentioned, has been at the forefront of recent studies and will not be separately reviewed here. The one aspect of that tragic situation that is important in the context of this narrative of the early reparations period is the internecine dispute between survivors who claimed a kind of first priority over any non-monetary gold found by occupation authorities and held by them and by the Tripartite Commission on the one hand, ${ }^{91}$ and the Jewish organizations which were entitled under the Paris Agreement to claim heirless assets on the other. That is a dispute that has continued, with various eruptions, to the present day in a variety of venues and over a great variety of property issues. ${ }^{92}$ This particular dispute was handled by means of a relatively generous definition of identifiable — and thus specifically restitutable — gold items, though the actual details of these cases have not been satisfactorily explored to this day.

\section{CONCLUSION}

The brief review of the recapture and reallocation of monetary gold among Allies in Part IV of this Article, with which this segment of the legal story concludes, illustrates more generally the nature of the reparations processes that took place under the umbrella of international agreements during the first halfdecade after the German surrender. ${ }^{93}$ The formerly occupied Allied

90. Smith, supra note 81, at 158; TRIPARTITE COMMISSION FOR THE RESTITUTION OF MONETARY GOLD, BRUSSEls, FINAL REPORT (Sept. 13, 1998), available at http://www.state.gov/s/1/65668.htm. The U.S.-Albanian Claims Settlement Agreement of April 18, 1995 made U.S. consent to this transfer contingent upon Albanian payment of $\$ 2,000,000$ to distribute to U.S. subjects holding certified claims from the Foreign Claims Settlement Commission for assets expropriated by the prior Albanian regime during the Cold War. The Agreement also requires Albania to afford national treatment under any domestic Albanian restitution or compensation laws to U.S. nationals who had suffered expropriation while still Albanian subjects.

91. Recall that the fund for stateless persons was to be generated in part from German assets liquidated in neutral countries, and in part from this non-monetary gold that was expected to be found only in Germany; see supra Part I.

92. For an early example, see Revici v. Conference of Jewish Material Claims Against Germany, Inc., 11 Misc. 2d 354, 174 N.Y.S.2d 825 (1958); for a more recent one, Wolf v. Germany \& Conference on Jewish Material Claims Against Germany, Inc., 95 F.3d 536 (7th Cir. 1996).

93. The parallel but separate issue of property restitution under pre-1949 Allied Occupation legislation, which focused, as the equivalent of German legislation, on the property claims of 
governments ${ }^{94}$ searched and scrabbled for identifiable and restitutable assets 95 while pursuing their evermore frustrated hopes and claims of participation in the reparations allocations of German and other Axis public and private propertyfrustrated in increasing degree by the policies of the United States. The individual victims' gold and other valuables became the subject of contentious claims among survivors and heirs, local associations of Jewish community remnants, and globally-focused Jewish organizations dedicated to the revival and support of Israel's and the Diaspora's communities.

The next chapter in the history of interstate reparations by Germany and in the intersection of private with state claims is beyond the scope of this Article. It began in 1950, when the major Allies' claims to reimbursement of their postwar expenditures and the perceived need to settle prewar Germany's public debts to its lenders, led to the London Debt Agreement of 1953. ${ }^{96}$ That Agreement set the stage for the next era of interstate reparations, one that lasted until the unification of Germany in 1990.

One preliminary conclusion now can be provided to the question posed at the outset of this discussion. The frustrations born of these decades-long struggles - frustrations felt intensely if differently by the formerly occupied Allies and by the individual and organizational victims - had to lead to major changes in the claims discourses of the later postwar eras. It is correct that at a relatively early next stage the mentioned Allies did move, albeit reluctantly, towards settling with the Federal Republic of Germany by means of the bilateral reparations treaties the London Debt Agreement permitted to be negotiated. ${ }^{97}$ Nonetheless, the resources generated through these treaty processes, even taken together, were not enough either to alleviate the victims' and survivors' plight, nor to satisfy the reparations expectations of the formerly occupied states. Thus the original disappointed expectations of the victims and survivors, combined with the inadequate outcomes of the later bilateral treaty processes, became a

persecuted German subjects, is another topic.

94. And, standing marginally under their governments' umbrellas, some private parties.

95. A particularly good example is that of the Government of the Netherlands seeking to increase its allocative share of the gold pool by claiming full restitution (or equivalent compensation), under the Italian Peace Treaty, of ingots looted by German occupation forces and transferred to Italy as a result of wartime transactions with Germany and Sweden respectively. The claim was rejected, and the Netherlands limited to its share of the pool. Case Concerning Gold Looted from the Netherlands, 44 I.L.R. 448 (Decision of the It.-Neth. Conciliation Comm'n of Aug. 17, 1963, 1972).

96. See Richard Buxbaum, The London Debt Agreement and Its Consequences, in BALANCING OF INTERESTS: LIBER AMICORUM 55 (Peter Hay ed., 2005).

97. Twelve such treaties were negotiated between 1959 and 1964 between the Federal Republic of Germany and both Allied Powers and Neutrals (in chronological order): Luxembourg, Norway, Greece, Denmark, the Netherlands, France, Belgium, Italy, Switzerland, Austria, the U.K. and Sweden. For citation to and review of these treaties, see ERNST FÉAUX DE LA CROIX, 3 DIE WiEDERGUTMACHUNG NATIONALSOZIALISTISCHEN UNRECHTS DURCH DIE BUNDESREPUBLIK DEUTSCHLAND: STAATSVERTRAGLICHE ERGÄNZUNGEN DER ENTSCHÄDIGUNG, in DER WERDEGANG DES ENTSCHÄDIGUNGSRECHTS 208ff (Bundesminister der Finanzen \& Walter Schwarz eds., 1985). 
significant element in fueling the long struggle to create legally binding rights of individuals against states under the mantle of international human rights. 